Zeszyty Naukowe Szkoły Głównej Gospodarstwa Wiejskiego w Warszawie

Problemy Rolnictwa Światowego tom 19 (XXXIV), zeszyt 3, 2019: 5-15

DOI: 10.22630/PRS.2019.19.3.41

Piotr Bórawski $^{1}$, Beata Kalinowska ${ }^{2}$, Zdzisław Kochanowicz ${ }^{3}$

${ }^{1,2}$ Uniwersytet Warmińsko-Mazurski w Olsztynie

${ }^{3}$ Wyższa Szkoła Agrobiznesu w Łomży

\title{
Zróżnicowanie czynników produkcji w gospodarstwach rolnych specjalizujących się $w$ chowie bydła mlecznego $w$ regionach FADN w Polsce w latach 2006-2017 na tle UE13 ${ }^{4}$
}

\section{Differentiation of Production Factors in Agricultural Farms Specializing in Dairy Cattle in FADN Regions in Poland in the Years 2006-2017 vis-à-vis the EU13}

\begin{abstract}
The paper analyzes total labor input, arable land area and the value of fixed assets on farms specializing in dairy cattle farming and conducting agricultural accounting by FADN. In addition, changes of the examined features for farms in FADN UE13 regions were presented. The research shows that the area of UAA on farms conducting agricultural accounting of FADN and dealing with dairy cattle farming increased during the examined period. Similar upward trends were observed in the case of fixed assets. The research shows that the highest value of fixed assets was recorded in 2014 in the FADN region of Pomerania and Mazury among four Polish regions and was at the level of 295.4 thousand. EUR per farm specializing in dairy farming. In turn, the lowest level of fixed assets value 46.3 thous. EUR occurred in 2006 in the FADN region of Lesser Poland and Pogórze.
\end{abstract}

Keywords: production factors, milk, EU countries.

\begin{abstract}
Synopsis. W pracy analizie poddano nakłady pracy ogółem, powierzchnię użytków rolnych i wartość majątku trwałego w gospodarstwach specjalizujących się w chowie bydła mlecznego i prowadzących rachunkowość rolną FADN. Ponadto przedstawiono zmiany badanych cech dla gospodarstw w regionach FADN UE13. Z badań wynika, że powierzchnia UR w gospodarstwach prowadzących rachunkowość rolną FADN i zajmujących się chowem bydła mlecznego uległa zwiększeniu w badanym okresie. Podobne tendencje wzrostowe zaobserwowano w przypadku wartości majątku trwałego. Z badań wynika, że najwyższą wartość majątku trwałego odnotowano w 2014 roku w regionie FADN Pomorze i Mazury spośród czterech regionów Polski i była na poziomie 295,4 tys. EUR na gospodarstwo rolne specjalizujące się w chowie bydła mlecznego. Z kolei najniższy poziom wartości aktywów trwałych 46,3 tys. EUR wystąpił w 2006 roku w regionie FADN Małopolska i Pogórze.
\end{abstract}

Słowa kluczowe: czynniki produkcji, mleko, kraje UE.

JEL Classification: F2, E60, L23, N50

\footnotetext{
${ }^{1}$ dr hab. inż., prof. UWM, Katadra Agrotechnologii, Zarządzania Produkcją Rolniczą i Agrobiznesu UWM, ul. M. Oczapowskiego 8, 10-719 Olsztyn, e-mail: pboraw@uwm.edu.pl; https://orcid.org/0000-0002-6616-7140 ${ }^{2}$ mgr, Katadra Agrotechnologii, Zarządzania Produkcją Rolniczą i Agrobiznesu UWM, ul. M. Oczapowskiego 8, 10-719 Olsztyn, e-mail: mcp2@wp.pl; https://orcid.org/0000-0001-9380-4419

${ }^{3}$ mgr, Wyższa Szkoła Agrobiznesu w Łomży, ul. Studencka 19, 18-402 Łomża; https://orcid.org/0000-0001-5043-2176

${ }_{4}$ Artykuł przygotowano $\mathrm{w}$ ramach projektu finansowanego przez Narodowe Centrum Nauki, numer 2018/29/B/HS4/00392.
} 


\section{Wstęp}

Początki klasyfikacji czynników produkcji sięgają XIX wieku do czasów ekonomisty Jeana-Baptiste's Saya. Ziemia, kapitał i praca należą do czynników produkcji, którym w literaturze przedmiotu poświęca się dużo uwagi (Czaja, Becla 2007). Czynniki te wykazują zróżnicowaną mobilność. Ziemia jest czynnikiem niemobilnym, nierozerwalnie związanym z danym terenem i ilościowo ograniczonym. Coraz większa ilość ziemi przeznaczana jest pod inne cele niż rolnictwo. Z kolei kapitał i praca są czynnikami mobilnymi i mogą być przemieszczane z miejsc o słabszym wykorzystaniu do terenów o większej efektywności ich wykorzystania (Bórawski 2013).

Aby rolnictwo polskie uzyskało wyższą konkurencyjność, powinno się zwiększyć ilość produkcji rolniczej, przy jednoczesnym ograniczeniu nakładów pracy i wzroście nakładów kapitałowych oraz wzroście koncentracji ziemi w rolnictwie (Kołodziejczak 2014).

Wielkość nakładów ziemi, pracy i majątku trwałego oraz efektywność gospodarstw jest zależna od wielkości zmian powierzchni obszarowej. W gospodarstwach, w których powiększył się obszar użytków rolnych w stosunku do gospodarstw, w których nie nastapiły zmiany powierzchni doszło do mniejszego poniesienia nakładów ziemi i pracy na jednostkę produkcji, a także wyniki ekonomiczne były znacznie wyższe w tych gospodarstwach (Sass 2009, Skarżyńska 2011, Wysokiński i Klepacki 2013, Sass 2015).

Czynniki produkcji a szczególnie zasoby ziemi, praca i środki trwałe, odgrywają ważne znaczenie w produkcji rolniczej, w tym w produkcji mleka. Spośród tych czynników produkcji szczególne znaczenie odgrywają zasoby ziemi oraz sposób jej zagospodarowania. Użytki rolne, w tym łąki i pastwiska są źródłem pasz objętościowych wykorzystywanych do karmienia bydła. Z badań Parzonko (2013) wynika, że regiony rozwijające produkcję mleka (podlaskie, część mazowieckiego i wielkopolskiego) charakteryzują się wyższym udziałem użytków zielonych w strukturze UR oraz niższą jakością gleb.

Polskie gospodarstwa mleczarskie w porównaniu do unijnych analizował Ziętara (2012) wykazując istotne różnice w produktywności czynników produkcji zarówno pracy, ziemi jak i kapitału. Nadal można zaobserwować różnice w produktywności poszczególnych czynników produkcji mleka w krajach członkowskich UE. Polskie gospodarstwa mleczne charakteryzują się niższą produkcją mleka, niższą wydajnością mleczną krów zbliżoną powierzchnią gospodarstw.

Mając na uwadze ważne znaczenie czynników produkcji w rozwoju polskiego mleczarstwa na jednolitym rynku UE, w pracy podjęto próbę oceny ich zmian. Szczególnie ważne są analizy gospodarstw prowadzących rachunkowość rolną FADN (Farm Accountancy Data Network) i zajmujących się produkcją mleka ponieważ baza FADN należy do najbardziej dokładnych i aktualnych źródeł informacji o gospodarstwach rolnych.

\section{Cel i metoda badań}

Celem badań było ocena regionalnego zróżnicowania poziomu nakładów pracy ogółem, powierzchni użytków rolnych oraz wartości majątku trwałego w gospodarstwach mlecznych uczestniczących w FADN UE. Cele szczegółowe to: ocena poziomu wartości majątku trwałego, powierzchni użytków rolnych poszczególnych regionów FADN Polski w odniesieniu do nakładów pracy ogółem. W artykule porównano dane za lata 2006-2017 dla regionów FADN UE 13 tj.: (0831) Severozapaden, (0832) Severen tsentralen, (0833) 
Severoiztochen, (0834) Yugozapaden, (0835) Yuzhen tsentralen, (0836) Yugoiztochen, (0745) Czech Republic, (0740) Cypr, (0755) Estonia, (0861) Jadranska Hrvatska, (0862) Kontinentalna Hrvatska, (0764) Észak-Magyarország, (0767) Alföld, (0768) Dunántúl, (0775) Lithuania, (0770) Latvia, (0780) Malta, (0785) Pomorze i Mazury, (0790) Wielkopolska i Śląsk, (0795) Mazowsze i Podlasie, (0800) Małopolska i Pogórze, (0840) Nord-Est, (0841) Sud-Est, (0842) Sud-Muntenia, (0843) Sud-Vest-Oltenia, (0844) Vest, (0845) Nord-Vest, (0846) Centru, (0847) Bucuresti-Ilfov, (0810) Slovakia, (0820) Slovenia

Do analizy wykorzystano następujące zmienne FADN UE 5

- SE010 - nakłady pracy ogółem - całkowite nakłady pracy ludzkiej w ramach działalności operacyjnej gospodarstwa rolnego $=$ AWU wyrażone $\mathrm{w}$ jednostkach przeliczeniowych pracy $=$ osobach pełnozatrudnionych $=2120$ godz. $/$ rok .

- SE025 - powierzchnia użytków rolnych w ha - całkowity obszar użytków rolnych ziemia własna, ziemia dodzierżawiona na jeden rok lub dłużej, ziemia współużytkowana z właścicielem na zasadzie udziału w zbiorach, a także ugory i odłogi.

- SE441 - aktywa trwałe w złotych - obejmują ziemię rolniczą, budynki gospodarstwa rolnego, nasadzenia leśne oraz maszyny $i$ urządzenia, a także zwierzęta stada podstawowego, a także środki trwałe będące $w$ fazie inwestycji.

\section{Wyniki badań}

Na początku dokonano charakterystyki zmian poziomu nakładów pracy ogółem, powierzchni użytków rolnych oraz poziomu wartości majątku trwałego gospodarstwa rolnych specjalizujących się $\mathrm{w}$ chowie bydła mlecznego w czterech regionach FADN w Polsce za lata 2006-2017.

Nakłady pracy ogółem w poszczególnych latach 2006-2017 w Polsce wg FADN w gospodarstwach rolnych specjalizujących się $\mathrm{w}$ chowie bydła mlecznego mieściły się $\mathrm{w}$ przedziale od 1,733 AWU do 1,930 AWU w gospodarstwie. Najwyższe średnie nakłady pracy ogółem (1,954 AWU na gospodarstwo) w badanym okresie odnotowano w regionie FADN Pomorze i Mazury (zróżnicowanie od 1,850 AWU do 2,06 AWU w gospodarstwie). Natomiast w regionie FADN Małopolska i Pogórze średnie nakłady pracy ogółem w badanym okresie były najniższe (1,647 AWU) i mieściły się w przedziale od 1,440 AWU do 2,010 AWU w gospodarstwie. W regionie FADN Wielkopolska i Śląsk nakłady pracy ogółem wykazywały również duże zróżnicowanie (od 1,780 AWU do 1,940 AWU w gospodarstwie). Natomiast $\mathrm{w}$ regionie FADN Mazowsze i Podlasie były w przedziale od 1,720 AWU do $1,850 \mathrm{AWU}$ w gospodarstwie.

Należy dodać, że najwyższy poziom nakładów pracy ogółem wystąpił w roku $2012 \mathrm{w}$ regionie FADN Pomorze i Mazury $(2,060)$ AWU na gospodarstwo rolne specjalizujące się w chowie bydła mlecznego i był wyższy o 1,000 AWU od średnich nakładów pracy ogółem w Polsce w 2010 roku. Najniższy poziom nakładów pracy ogółem (1,5870 AWU) wystapił w roku 2010 w regionie FADN Małopolska i Pogórze. Należy dodać że średnia roczna wartość AWU we wszystkich regionach FADN mieściła się w zakresie od 1,647 do 1,954 AWU i była (poza Mazowsze i Podlasie) wyższa od wielkości z roku 2017. Wskazuje to na fakt, że prawie we wszystkich regionach (oprócz Mazowsza i Podlasia) nakłady pracy miały tendencje malejące w okresie 2006-2017 (tab. 1). Powodem tego

${ }^{5}$ [https://ec.europa.eu/agriculture/rica/database/database_en.cfm]:dostęp 10.07.2019.20,44. 


\section{P. Bórawski, B. Kalinowska, Z. Kochanowicz}

zjawiska może być substytucja pracy ludzkiej przez pracę uprzedmiotowioną. Rolnicy w gospodarstwach rolnych przeprowadzają inwestycje, które unowocześniają technologie produkcji i wymagają mniejszych nakładów pracy ludzkiej. Ponadto jak wskazuje Grzelak (2015) istnieje silna presja na zwiększenie wydajności tego czynnika produkcji.

Tabela 1. Nakłady pracy ogółem na jedno gospodarstwo rolne specjalizujące się w chowie bydła mlecznego w poszczególnych regionach FADN oraz średnia dla Polski w latach 2006-20017 (AWU)

Table 1. Total workload per one agricultural holding specializing in dairy cattle farming in individual FADN regions and average for Poland in 2006-20017 (AWU)

\begin{tabular}{|c|c|c|c|c|c|c|c|c|c|c|c|c|c|}
\hline \multicolumn{13}{|c|}{ Nakłady pracy ogółem (SE010) w poszczególnych latach } & \multirow{2}{*}{$\begin{array}{c}\text { Średnia } \\
\text { w latach } \\
2006- \\
20017\end{array}$} \\
\hline Regiony & 2006 & 2007 & 2008 & 2009 & 2010 & 2011 & 2012 & 2013 & 2014 & 2015 & 2016 & 2017 & \\
\hline $\begin{array}{l}\text { Pomorze i } \\
\text { Mazury }\end{array}$ & 1,970 & 1,850 & 1,960 & 1,900 & 1,920 & 2,020 & 2,060 & 2,010 & 1,990 & 1,980 & 1,920 & 1,870 & 1,954 \\
\hline $\begin{array}{l}\text { Wielkopols } \\
\text { ka i Śląsk }\end{array}$ & 1,800 & 1,890 & 1,940 & 1,840 & 1,830 & 1,890 & 1,850 & 1,820 & 1,850 & 1,780 & 1,780 & 1,780 & 1,838 \\
\hline $\begin{array}{l}\text { Mazowsze i } \\
\text { Podlasie }\end{array}$ & 1,750 & 1,800 & 1,790 & 1,790 & 1,770 & 1,800 & 1,820 & 1,830 & 1,720 & 1,820 & 1,790 & 1,850 & 1,794 \\
\hline $\begin{array}{l}\text { Małopolska } \\
\text { i Pogórze }\end{array}$ & 1,590 & 1,580 & 1,630 & 1,540 & 1,490 & 2,010 & 1,620 & 1,660 & 1,880 & 1,750 & 1,440 & 1,570 & 1,647 \\
\hline $\begin{array}{r}\text { Średnia dla } \\
\text { Polski }\end{array}$ & 1,778 & 1,780 & 1,830 & 1,768 & 1,753 & 1,930 & 1,838 & 1,830 & 1,860 & 1,833 & 1,733 & 1,768 & 1,808 \\
\hline
\end{tabular}

Zasoby ziemi są czynnikiem decydującym o możliwościach rozwoju produkcji mleka. $\mathrm{Z}$ danych zawartych w tabeli 2 wynika, że w Polsce w badanym okresie wg danych FADN w gospodarstwach rolnych specjalizujących się w chowie bydła mlecznego średnia powierzchnia UR była na poziomie 20,49 ha. W regionie FADN Pomorze i Mazury powierzchnia UR w latach 2006-2017 wynosiła średnio w roku 32,66 ha i była ona wyższa od średniej w Polsce o 12,17 ha. W analogicznym okresie średnia powierzchnia użytków rolnych w regionie FADN Wielkopolska i Sląsk wynosiła 24,21 ha i była wyższa o 3,72 ha od średniej W Polsce w gospodarstwie rolnym specjalizującym się w chowie bydła mlecznego.

W dwóch regionach FADN Mazowsze i Podlasie oraz Małopolska i Pogórze średnio w roku powierzchnia użytków rolnych $\mathrm{w}$ badanym okresie była na poziomie (odpowiednio19,80 ha i 11,82 ha) na jedno gospodarstwo rolne specjalizujące się w chowie bydła mlecznego i była ona niższa niż średnia w roku powierzchnia użytków rolnych w Polsce (odpowiednio o 0,690 ha i 8,67 ha) w gospodarstwie.

Powierzchnia użytków rolnych w latach 2006-2017 wg danych FADN w Polsce, w gospodarstwach rolnych specjalizujących się $\mathrm{w}$ chowie bydła mlecznego mieściła się $\mathrm{w}$ przedziale od 18,27 ha do 21,91 ha. W regionie FADN Pomorze i Mazury powierzchnia użytków rolnych mieściła się w przedziale od 27,91 ha do 35,30 ha w gospodarstwie, w regionie FADN Wielkopolska i Sląsk od 22,99 ha do 26,73 ha, w regionie FADN Mazowsze i Podlasie od 16,84 ha do 21,81 ha, a w regionie FADN Małopolska i Pogórze od 9,84 ha do 13,52 ha. Z danych wynika, że dwa regiony FADN Pomorze i Mazury oraz Wielkopolska i Śląsk posiadały największą powierzchnię UR, a tym samym możliwości zwiększenia produkcji roślinnej na potrzeby chowu krów i bydła. 
W latach 2006-2017 powierzchnie gospodarstw w regionach uległy nieznacznemu zwiększeniu, oprócz regionu Pomorze i Mazury gdzie powierzchnia uległa zmniejszeniu (tab. 2).

Tabela 2. Powierzchnia użytków rolnych na jedno gospodarstwo rolne specjalizujące się w chowie bydła mlecznego w poszczególnych regionach FADN oraz w całej Polsce (ha)

Table 2. Area of agricultural land per one agricultural holding specializing in dairy cattle breeding in individual FADN regions and throughout Poland (ha)

\begin{tabular}{|c|c|c|c|c|c|c|c|c|c|c|c|c|c|}
\hline \multicolumn{13}{|c|}{ Powierzchnia użytków rolnych (SE025) w poszczególnych latach } & \multirow{2}{*}{$\begin{array}{l}\text { Średnio } \\
\text { w latach } \\
-2006- \\
20017\end{array}$} \\
\hline Regiony & 2006 & 2007 & 2008 & 2009 & 2010 & 2011 & 2012 & 2013 & 2014 & 2015 & 2016 & 2017 & \\
\hline $\begin{array}{l}\text { Pomorze i } \\
\text { Mazury }\end{array}$ & 33,41 & 27,91 & 33,02 & 29,23 & 32,06 & 34,95 & 35,30 & 33,86 & 35,00 & 35,08 & 32,09 & 30,03 & 32,66 \\
\hline $\begin{array}{l}\text { Wielkopols } \\
\text { ka i Śląsk }\end{array}$ & 23,12 & 24,75 & 26,73 & 23,96 & 24,42 & 24,54 & 22,99 & 23,50 & 25,15 & 23,71 & 23,81 & 23,94 & 24,21 \\
\hline $\begin{array}{l}\text { Mazowsze i } \\
\text { Podlasie }\end{array}$ & 16,84 & 18,40 & 18,53 & 19,10 & 19,33 & 19,74 & 20,41 & 21,27 & 20,47 & 21,81 & 21,01 & 20,80 & 19,80 \\
\hline $\begin{array}{l}\text { Małopolska } \\
\text { i Pogórze }\end{array}$ & 9,84 & 10,34 & 11,42 & 10,93 & 11,26 & 13,52 & 12,58 & 12,94 & 13,40 & 12,71 & 11,35 & 11,66 & 11,82 \\
\hline Polska & 18,27 & 18,87 & 19,79 & 19,72 & 20,18 & 21,30 & 21,14 & 21,56 & 21,44 & 21,91 & 20,96 & 20,76 & 20,49 \\
\hline
\end{tabular}

Ważnym czynnikiem decydującym o rozwoju produkcji mleka są aktywa trwałe, których średnia wartość w Polsce w latach 2006-2017 wg danych FADN w gospodarstwach rolnych specjalizujących się w chowie bydła mlecznego była na poziomie 162,7 tys. EUR. W regionie FADN Pomorze i Mazury oraz Wielkopolska i Śląsk w badanym okresie wartość aktywów trwałych wyniosła średnio w roku (odpowiednio 212,0 tys. EUR oraz 203,6 tys. EUR) i była wyższa od średniej w Polsce (o 49,3 tys. EUR i 40,90 tys. EUR).

$\mathrm{Z}$ kolei w regionie FADN Mazowsze i Podlasie średnio w roku wartość aktywów trwałych w badanym okresie była równa średniej w Polsce (162,7 tys. EUR). Najniższa średnia w roku wartość aktywów trwałych w latach 2006-2017 była w regionie FADN Małopolska i Pogórze (143,6 tys. EUR) i była ona niższa od średniej w roku wartości aktywów trwałych w Polsce o 16,10 tys. EUR.

Wartość majątku trwałego w poszczególnych latach 2006-2017 w Polsce w gospodarstwach rolnych specjalizujących się w chowie bydła mlecznego mieściła się w przedziale od 746,0 tys. EUR do 210,6 tys. EUR w gospodarstwie. W regionie FADN Pomorze i Mazury wartość ta była w przedziale od 91,7 tys. EUR do 295,4 tys. EUR w gospodarstwie, w regionie FADN Wielkopolska i Śląsk od 90,4 tys. EUR do 266,0 tys. EUR, w regionie FADN Mazowsze i Podlasie od 75,7 tys. EUR do 213,0 tys. EUR, natomiast $\mathrm{w}$ regionie FADN Małopolska i Pogórze od 46,3 tys. EUR do 66,7 tys. EUR. Wartość majątku trwałego gospodarstw mlecznych w Polsce w ciągu okresu 2006-2017 zwiększyła się o 2,73 razy, natomiast w regionie Wielkopolska i Śląsk o 2,90 razy. Zdaniem Grzelaka (2015) zmiany wartości majątku trwałego w gospodarstwach prowadzących rachunkowość rolną FADN mają charakter trwały i zależą raczej od wsparcia inwestycji w ramach wspólnej polityki rolnej niż od koniunktury (tab. 3).

Najwyższa wartość aktywów trwałych była w roku 2014 w regionie FADN Pomorze i Mazury i była na poziomie 295,4 tys. EUR w gospodarstwie rolnym specjalizującym się w chowie bydła mlecznego i była ona wyższa o 84,8 tys. EUR od średniej w Polsce w 2014 
roku. Najniższa wartość aktywów trwałych (46,3 tys. EUR) wystapiła w roku 2006 w regionie FADN Małopolska i Pogórze i była niższa o 28,3 tys. EUR od średniej w Polsce w 2006 roku. Głównym powodem słabszej kondycji ekonomicznej gospodarstw w Polsce i gorszego wyposażenia w aktywa w porównaniu do bardziej rozwiniętych krajów UE może być zdaniem Czyżewskiego i Kryszaka (2015) obok wielkości finansowego wsparcia w ramach WPR, niekorzystna struktura agrarna. Pomimo przeprowadzanych inwestycji w gospodarstwach rolnych polskie rolnictwo zarówno u progu akcesji do UE jak i współcześnie charakteryzowało się niewątpliwie znacznie niższym stopniem mechanizacji.

Tabela 3. Aktywa trwałe średnio rocznie na jedno gospodarstwo rolne specjalizujące się w chowie bydła mlecznego w poszczególnych regionach FADN oraz w całej Polsce (tys. EUR)

Table 3. Fixed assets on average per year per one agricultural holding specializing in dairy cattle breeding in individual FADN regions and throughout Poland (thousand EUR)

\begin{tabular}{|c|c|c|c|c|c|c|c|c|c|c|c|c|c|}
\hline \multicolumn{13}{|c|}{ Aktywa trwałe (SE441) w poszczególnych latach w tys. EUR } & \multirow{2}{*}{$\begin{array}{c}\text { Średnio } \\
\text { w roku } \\
\text { - w latach } \\
2006-2017 \\
\end{array}$} \\
\hline Regiony & 2006 & 2007 & 2008 & 2009 & 2010 & 2011 & 2012 & 2013 & 2014 & 2015 & 2016 & 2017 & \\
\hline $\begin{array}{l}\text { Pomorze i } \\
\text { Mazury }\end{array}$ & 91,7 & 100,0 & 130,8 & 175,4 & 207,7 & 229,6 & 253,0 & 255,8 & 295,4 & 289,4 & 256,4 & 259,3 & 212,0 \\
\hline $\begin{array}{l}\text { Wielkopols } \\
\text { ka i Śląsk }\end{array}$ & 90,4 & 112,5 & 135,9 & 196,3 & 216,4 & 213,6 & 214,8 & 235,8 & 266,0 & 252,3 & 247,9 & 261,7 & 203,6 \\
\hline $\begin{array}{l}\text { Mazowsze i } \\
\text { Podlasie }\end{array}$ & 75,7 & 92,5 & 102,4 & 145,5 & 163,0 & 167,3 & 178,9 & 198,1 & 204,7 & 213,0 & 202,2 & 208,7 & 162,7 \\
\hline $\begin{array}{l}\text { Małopolska } \\
\text { i Pogórze }\end{array}$ & 46,3 & 55,0 & 66,7 & 77,7 & 91,7 & 123,6 & 103,3 & 113,8 & 129,9 & 109,7 & 109,4 & 95,0 & 143,6 \\
\hline Polska & 74,6 & 89,2 & 103,2 & 145,8 & 164,4 & 175,3 & 181,0 & 196,2 & 210,6 & 209,6 & 199,1 & 203,3 & 162,7 \\
\hline
\end{tabular}

Źródło: opracowanie własne na podstawie danych FADN.

W tabeli 4 przedstawiono zmiany w nakładach pracy ogółem, powierzchni użytków rolnych oraz wartości aktywów trwałych w latach 2006-2017 w gospodarstwach prowadzących rachunkowość rolną w regionach FADN w krajach UE 13.

Z analizy wynika, że największy wzrost nakładów pracy ogółem w latach 2006-2017 odnotowano $w$ regionach FADN UE13 tj.: (0836) Yugoiztochen $(43,92 \%)$, (0833) Severoiztochen $(29,25 \%)$, (0834) Yugozapaden $(26,92 \%)$, (0832) Severen tsentralen $(22,03 \%)$ i (0831) Severozapaden (17,10\%). Natomiast największe spadki nakładów pracy ogółem nastąpiły w regionach FADN UE13 takich jak: (0841) Sud-Est (-41,72\%), (0810) Slovakia $(-32,74 \%),(0842)$ Sud-Muntenia $(-27,34 \%),(0845)$ Nord-Vest $(-25,32)$ i $(0768)$ Dunántúl $(-25,30 \%)$.

Analizując powierzchnię użytków rolnych $\mathrm{w}$ gospodarstwach zajmujących się chowem bydła mlecznego za lata 2006-2017 można zauważyć, że największy wzrost powierzchni użytków rolnych był w regionach FADN UE13 takich jak: (836) Yugoiztochen (371,16\%), (833) Severoiztochen (358,06\%), (831) Severozapaden (175,89\%), (768) Dunántúl (124,38\%) i (832) Severen tsentralen (116,11\%). Z kolei największy spadek powierzchni użytków rolnych wystąpił w następujących regionach FADN UE13: (0842) Sud-Muntenia (-66,41\%), (0846) Centru (-24,74\%), (0861) Jadranska Hrvatska (-2159), (0840) Nord-Est (-19,96\%) i (0780) Malta (-18,95\%).

Wartość aktywów trwałych w gospodarstwach rolnych zajmujących się chowem bydła mlecznego w badanym okresie wzrosła najwięcej w regionach FADN UE13 takich jak: (0836) Yugoiztochen (374,31\%), (0833) Severoiztochen (314,48\%),(0831) Severozapaden 
(289,17\%), (0768) Dunántúl (195,21\%) i (0790) Wielkopolska i Śląsk (189,62\%). Natomiast największy spadek wartości aktywów trwałych odnotowano w następujących regionach FADN UE13: (0842) Sud-Muntenia (-47,65\%), (0810) Slovakia (-30,89\%), (0861) Jadranska Hrvatska(-18,59\%) i (0780) Malta (-10,24\%).

Tabela 4. Zmiany w zasobach czynników produkcji w regionach FADN krajów UE13 w gospodarstwach mleczarskich w Unii Europejskiej za okres 2006-2017

Table 4. Changes in the resources of production factors in the FADN regions of the EU13 countries in dairy farms in the European Union for the period 2006-2017

\begin{tabular}{|c|c|c|c|c|c|c|c|c|c|c|}
\hline \multirow{2}{*}{$\begin{array}{l}\text { Kraje } \\
\text { UE13 }\end{array}$} & \multirow{2}{*}{$\begin{array}{c}\text { Regiony FADN } \\
\text { UE13 }\end{array}$} & \multicolumn{3}{|c|}{$\begin{array}{l}\text { Nakłady pracy ogółem } \\
\text { (SE010) w AWU }\end{array}$} & \multicolumn{3}{|c|}{$\begin{array}{l}\text { Powierzchnia użytków } \\
\text { rolnych (SE025) w ha }\end{array}$} & \multicolumn{3}{|c|}{$\begin{array}{c}\text { Aktywa trwałe (SE441) } \\
\text { w tys. EUR }\end{array}$} \\
\hline & & 2006 & 2017 & $\underset{\%}{Z \text { miany }}$ & 2006 & 2017 & $\underset{\%}{Z \text { miany }}$ & 2006 & 2017 & $\underset{\%}{Z}$ \\
\hline \multirow{6}{*}{ BGR } & $(0831)$ & 1,93 & 2,26 & 17,10 & 5,35 & 14,76 & 175,89 & 10,9 & 42,2 & 289,17 \\
\hline & (0832) & 1,77 & 2,16 & 22,03 & 8,13 & 17,57 & 116,11 & 21,7 & 45,1 & 108,34 \\
\hline & (0833) & 2,12 & 2,74 & 29,25 & 3,72 & 17,04 & 358,06 & 12,6 & 52,2 & 314,48 \\
\hline & (0834) & 1,82 & 2,31 & 26,92 & 12,39 & 21,61 & 74,41 & 19,6 & 34,9 & 78,36 \\
\hline & (0835) & 2,25 & 2,00 & $-11,11$ & 8,42 & 10,77 & 27,91 & 21,2 & 31,0 & 46,14 \\
\hline & (0836) & 1,89 & 2,72 & 43,92 & 6,97 & 32,84 & 371,16 & 12,8 & 60,6 & 374,31 \\
\hline CYP & $(0740)$ & $\mathrm{b} / \mathrm{d}$ & $\mathrm{b} / \mathrm{d}$ & $\mathrm{b} / \mathrm{d}$ & $\mathrm{b} / \mathrm{d}$ & $\mathrm{b} / \mathrm{d}$ & $\mathrm{b} / \mathrm{d}$ & $\mathrm{b} / \mathrm{d}$ & $\mathrm{b} / \mathrm{d}$ & $\mathrm{b} / \mathrm{d}$ \\
\hline CZE & $(0745)$ & 9,51 & 9,38 & $-1,37$ & 230,31 & 253,01 & 9,86 & 576,3 & 736,2 & 27,75 \\
\hline EST & $(0755)$ & 5,49 & 4,4 & $-19,85$ & 195,51 & 214,51 & 9,72 & 229,3 & 562,4 & 145,28 \\
\hline \multirow{2}{*}{ HRV } & $(0861)$ & 2,27 & 2,31 & 1,76 & 17,51 & 13,73 & $-21,59$ & 152,2 & 123,9 & $-18,59$ \\
\hline & (0862) & 2,03 & 2,02 & $-0,49$ & 16,34 & 16,51 & 1,04 & 109,0 & 114,6 & 5,14 \\
\hline \multirow{3}{*}{ HUN } & (0764) & $\mathrm{b} / \mathrm{d}$ & $\mathrm{b} / \mathrm{d}$ & $\mathrm{b} / \mathrm{d}$ & $\mathrm{b} / \mathrm{d}$ & $\mathrm{b} / \mathrm{d}$ & $\mathrm{b} / \mathrm{d}$ & $\mathrm{b} / \mathrm{d}$ & $\mathrm{b} / \mathrm{d}$ & $\mathrm{b} / \mathrm{d}$ \\
\hline & (0767) & 2,57 & 2,08 & $-19,07$ & 46,14 & 43,34 & $-6,07$ & 90,1 & 128,8 & 42,92 \\
\hline & (0768) & 6,6 & 4,93 & $-25,30$ & 52,33 & 117,42 & 124,38 & 121,7 & 359,3 & 195,21 \\
\hline LTU & $(0775)$ & 1,63 & 1,59 & $-2,45$ & 23,61 & 29,46 & 24,78 & 37,8 & 61,5 & 62,74 \\
\hline LVA & $(0770)$ & 2,12 & 1,95 & $-8,02$ & 47,62 & 49,9 & 4,79 & 38,7 & 77,3 & 99,75 \\
\hline MLT & $(0780)$ & 2,29 & 2,27 & $-0,87$ & 4,75 & 3,85 & $-18,95$ & 745,1 & 668,8 & $-10,24$ \\
\hline \multirow{4}{*}{ POL } & $(0785)$ & 1,97 & 1,87 & $-5,08$ & 33,41 & 30,03 & $-10,12$ & 91,7 & 259,3 & 182,78 \\
\hline & (0790) & 1,8 & 1,78 & $-1,11$ & 23,12 & 23,94 & 3,55 & 90,4 & 261,7 & 189,62 \\
\hline & (0795) & 1,75 & 1,85 & 5,71 & 16,84 & 20,8 & 23,52 & 75,7 & 208,7 & 175,68 \\
\hline & (0800) & 1,59 & 1,57 & $-1,26$ & 9,84 & 11,66 & 18,50 & 46,3 & 95,0 & 105,21 \\
\hline \multirow{8}{*}{ ROU } & $(0840)$ & 1,16 & 0,9 & $-22,41$ & 5,26 & 4,21 & $-19,96$ & 14,5 & 19,0 & 30,55 \\
\hline & $(0841)$ & 1,51 & 0,88 & $-41,72$ & 2,53 & 3,9 & 54,15 & 16,3 & 26,7 & 64,34 \\
\hline & $(0842)$ & 1,39 & 1,01 & $-27,34$ & 7,65 & 2,57 & $-66,41$ & 38,2 & 20,0 & $-47,65$ \\
\hline & (0843) & 1,37 & 1,08 & $-21,17$ & 3,18 & 3,46 & 8,81 & 15,8 & 20,1 & 27,20 \\
\hline & (0844) & 1,23 & 1,11 & $-9,76$ & 5,81 & 8,19 & 40,96 & 38,2 & 43,0 & 12,58 \\
\hline & $(0845)$ & 1,58 & 1,18 & $-25,32$ & 6,83 & 5,9 & $-13,62$ & 24,7 & 28,7 & 16,16 \\
\hline & (0846) & 1,38 & 1,15 & $-16,67$ & 9,66 & 7,27 & $-24,74$ & 38,0 & 47,6 & 25,17 \\
\hline & (0847) & 1,51 & $\mathrm{~b} / \mathrm{d}$ & $\mathrm{b} / \mathrm{d}$ & 1,97 & $\mathrm{~b} / \mathrm{d}$ & $\mathrm{b} / \mathrm{d}$ & 41,1 & $\mathrm{~b} / \mathrm{d}$ & $\mathrm{b} / \mathrm{d}$ \\
\hline SVK & $(0810)$ & 33,41 & 22,47 & $-32,74$ & 968,5 & 861,04 & $-11,10$ & 2005,1 & 1385,7 & $-30,89$ \\
\hline SVN & $(0820)$ & 2,15 & 1,69 & $-21,40$ & 13,95 & 16,9 & 21,15 & 228,5 & 324,8 & 42,12 \\
\hline
\end{tabular}

Źródło: opracowanie własne na podstawie danych FADN UE. 


\section{P. Bórawski, B. Kalinowska, Z. Kochanowicz}

W tabeli 5 przedstawiono zmiany w nakładach pracy ogółem, powierzchni użytków rolnych oraz wartości aktywów trwałych w latach 2006-2017 w gospodarstwach prowadzących rachunkowość rolną FADN w krajach UE13.

Z analizy wynika, że największy wzrost nakładów pracy ogółem w latach 2006-2017 odnotowano w Bułgarii $(17,01 \%)$ i Polsce $(2,86 \%)$. Natomiast w badanym okresie największe spadki nakładów pracy ogółem nastapiły w Rumunii $(-43,72 \%)$, Słowacji ($32,74 \%)$ i Słowenii $(-21,40)$.

Analizując powierzchnię użytków rolnych w gospodarstwach zajmujących się chowem bydła mlecznego i prowadzących rachunkowość rolną FADN za lata 2006-2017 można zauważyć, że największy wzrost powierzchni użytków rolnych był w Bułgarii $(155,98 \%)$, Litwie $(24,78 \%)$ i Rumunii $(15,08 \%)$. Natomiast największy spadek powierzchni użytków rolnych wystapił na Węgrzech $(-20,62 \%)$, Malcie $(-18,94 \%)$ i Słowacji $(-11,10)$.

Wartość aktywów trwałych w gospodarstwach rolnych zajmujących się chowem bydła mlecznego w badanym okresie wzrosła najwięcej w Bułgarii (902,44\%), Polsce (172,52\%) i Estonii $(145,38 \%)$. Natomiast największy spadek wartości aktywów trwałych odnotowano na Słowacji $(-30,89 \%)$ i Malcie $(-10,24 \%)$.

Tabela 5. Zmiany w zasobach czynników produkcji w krajach UE13 w gospodarstwach mleczarskich w Unii Europejskiej za okres 2006-2017 roku

Table 5. Changes in the resources of production factors in the EU13 countries in dairy farms in the European Union for the period 2006-2017

\begin{tabular}{|c|c|c|c|c|c|c|c|c|c|}
\hline \multirow{2}{*}{ Kraje EU13 } & \multicolumn{3}{|c|}{$\begin{array}{l}\text { Nakłady pracy ogółem } \\
\text { (SE010) w AWU }\end{array}$} & \multicolumn{3}{|c|}{$\begin{array}{l}\text { Powierzchnia użytków rolnych } \\
\text { (SE025) w ha }\end{array}$} & \multicolumn{3}{|c|}{$\begin{array}{c}\text { Aktywa trwałe (SE441) w tys. } \\
\text { EUR }\end{array}$} \\
\hline & 2006 & 2017 & Zmiany \% & 2006 & 2017 & Zmiany \% & 2006 & 2017 & Zmiany \% \\
\hline Bułgaria $^{1}$ & 1,94 & 2,27 & 17,01 & 6,61 & 16,92 & 155,98 & 4,1 & 41,1 & 902,44 \\
\hline Cypr $^{2}$ & $\mathrm{~b} / \mathrm{d}$ & $\mathrm{b} / \mathrm{d}$ & $\mathrm{b} / \mathrm{d}$ & $\mathrm{b} / \mathrm{d}$ & $\mathrm{b} / \mathrm{d}$ & $\mathrm{b} / \mathrm{d}$ & $\mathrm{b} / \mathrm{d}$ & $\mathrm{b} / \mathrm{d}$ & $\mathrm{b} / \mathrm{d}$ \\
\hline Czechy & 9,51 & 9,38 & $-1,37$ & 230,31 & 253,01 & 9,86 & 576,2 & 736,2 & 27,77 \\
\hline Estonia & 5,49 & 4,4 & $-19,85$ & 195,51 & 214,51 & 9,72 & 229,2 & 562,4 & 145,38 \\
\hline Chorwacja $^{3}$ & 2,05 & 2,05 & 0,00 & 16,45 & 16,15 & $-1,82$ & 113,12 & 115,7 & 2,28 \\
\hline Węgry & 3,02 & 2,52 & $-16,56$ & 69,74 & 55,36 & $-20,62$ & 126,6 & 164,6 & 30,02 \\
\hline Litwa & 1,63 & 1,59 & $-2,45$ & 23,61 & 29,46 & 24,78 & 37,8 & 61,5 & 62,70 \\
\hline Lotwa & 2,12 & 1,95 & $-8,02$ & 47,62 & 49,9 & 4,79 & 38,6 & 77,3 & 100,26 \\
\hline Malta & 2,29 & 2,27 & $-0,87$ & 4,75 & 3,85 & $-18,95$ & 745 & 668,7 & $-10,24$ \\
\hline Polska & 1,75 & 1,80 & 2,86 & 18,27 & 20,76 & 13,63 & 74,6 & 203,3 & 172,52 \\
\hline Rumunia $^{4}$ & 1,83 & 1,03 & $-43,72$ & 4,31 & 4,96 & 15,08 & 15,8 & 28 & 77,22 \\
\hline Słowacja & 33,41 & 22,47 & $-32,74$ & 968,5 & 861,04 & $-11,10$ & 2005 & 1385,6 & $-30,89$ \\
\hline Słowenia & 2,15 & 1,69 & $-21,40$ & 13,95 & 16,9 & 21,15 & 228,5 & 324,7 & 42,10 \\
\hline
\end{tabular}

1 - dane od 2007 r., 2 - brak danych, 3 - dane od 2013 r., 4 - dane od 2007 r.

Źródło: opracowanie własne na podstawie danych FADN UE.

Cennych informacji dostarcza ocena poziomu wartości majątku trwałego i powierzchni użytków rolnych $w$ stosunku do nakładów pracy (zatrudnienia) w gospodarstwach mlecznych regionów FADN UE13 (tab. 6). Wyniki analiz wskazują że najwyższą powierzchnię UR na 1 zatrudnianego $\mathrm{w}$ gospodarstwie zaobserwowano w regionie (0755) Estonia (48,75 ha), a najniższą w regionie (0780) Malta (1,67 ha). Regiony FADN w Polsce wykazuja wskaźnik w granicach 7,42-16,05 ha, który oscyluje wokół średniej dla FADN UE13 (12,78 ha). 
Tabela 6. Ocena wartości majątku trwałego i powierzchni użytków rolnych w odniesieniu do nakładów pracy ogółem w regionach FADN UE13 w gospodarstwach mleczarskich (tys. EUR)

Table 6. Assessment of the value of fixed assets and agricultural area in relation to total labor input in FADN UE13 regions in dairy farms (thousand EUR)

\begin{tabular}{|c|c|c|c|c|c|c|c|}
\hline \multirow{2}{*}{$\begin{array}{l}\text { Kraje } \\
\text { UE13 }\end{array}$} & \multirow{2}{*}{$\begin{array}{c}\text { Regiony FADN } \\
\text { UE13 }\end{array}$} & \multicolumn{3}{|c|}{ SE025/SE010 } & \multicolumn{3}{|c|}{ SE441/SE010 } \\
\hline & & SE025 & SE010 & Wskaźnik & SE441 & SE010 & Wskaźnik \\
\hline \multirow{6}{*}{ BGR } & $(0831)$ & 14,76 & 2,26 & 6,53 & 42,20 & 2,26 & 18,67 \\
\hline & (0832) & 17,57 & 2,16 & 8,13 & 45,10 & 2,16 & 20,88 \\
\hline & $(0833)$ & 17,04 & 2,74 & 6,21 & 52,20 & 2,74 & 19,05 \\
\hline & (0834) & 21,61 & 2,31 & 9,35 & 34,90 & 2,31 & 15,11 \\
\hline & (0835) & 10,77 & 20 & 5,38 & 31,00 & 2,00 & 15,50 \\
\hline & $(0836)$ & 32,84 & 2,72 & 12,07 & 60,60 & 2,72 & 22,28 \\
\hline CYP & $(0740)$ & $\mathrm{b} / \mathrm{d}$ & $\mathrm{b} / \mathrm{d}$ & $\mathrm{b} / \mathrm{d}$ & $\mathrm{b} / \mathrm{d}$ & $\mathrm{b} / \mathrm{d}$ & $\mathrm{b} / \mathrm{d}$ \\
\hline $\mathrm{CZE}$ & $(0745)$ & 253,01 & 9,38 & 26,97 & 736,20 & 9,38 & 78,49 \\
\hline EST & $(0755)$ & 214,51 & 4,40 & 48,75 & 562,40 & 4,40 & 127,82 \\
\hline \multirow{2}{*}{ HRV } & (0861) & 13,73 & 2,31 & 5,94 & 123,90 & 2,31 & 53,64 \\
\hline & $(0862)$ & 16,51 & 2,02 & 8,17 & 114,60 & 2,02 & 56,73 \\
\hline \multirow{3}{*}{ HUN } & (0764) & $\mathrm{b} / \mathrm{d}$ & $\mathrm{b} / \mathrm{d}$ & $\mathrm{b} / \mathrm{d}$ & $\mathrm{b} / \mathrm{d}$ & $\mathrm{b} / \mathrm{d}$ & $b / d$ \\
\hline & (0767) & 43,34 & 2,08 & 20,83 & 128,80 & 2,08 & 61,92 \\
\hline & $(0768)$ & 117,42 & 4,93 & 23,81 & 359,30 & 4,93 & 72,88 \\
\hline LTU & $(0775)$ & 29,46 & 1,59 & 18,52 & 61,50 & 1,59 & 38,68 \\
\hline LVA & $(0770)$ & 49,9 & 1,95 & 25,58 & 77,30 & 1,95 & 39,64 \\
\hline MLT & $(0780)$ & 3,85 & 2,27 & 1,69 & 668,80 & 2,27 & 294,63 \\
\hline \multirow{4}{*}{ POL } & (0785) & 30,03 & 1,87 & 16,05 & 259,30 & 1,87 & 138,66 \\
\hline & (0790) & 23,94 & 1,78 & 13,44 & 261,70 & 1,78 & 147,02 \\
\hline & (0795) & 20,8 & 1,85 & 11,24 & 208,70 & 1,85 & 112,81 \\
\hline & $(0800)$ & 11,66 & 1,57 & 7,42 & 95,00 & 1,57 & 60,51 \\
\hline \multirow{8}{*}{ ROU } & $(0840)$ & 4,21 & 0,90 & 4,67 & 19,00 & 0,90 & 21,11 \\
\hline & (0841) & 3,9 & 0,88 & 4,43 & 26,70 & 0,88 & 30,34 \\
\hline & (0842) & 2,57 & 1,01 & 2,54 & 20,00 & 1,01 & 19,80 \\
\hline & (0843) & 3,46 & 1,08 & 3,20 & 20,10 & 1,08 & 18,61 \\
\hline & (0844) & 8,19 & 1,11 & 7,37 & 43,00 & 1,11 & 38,74 \\
\hline & (0845) & 5,9 & 1,18 & 5,00 & 28,70 & 1,18 & 24,32 \\
\hline & (0846) & 7,27 & 1,15 & 6,32 & 47,60 & 1,15 & 41,39 \\
\hline & $(0847)$ & $\mathrm{b} / \mathrm{d}$ & $\mathrm{b} / \mathrm{d}$ & $\mathrm{b} / \mathrm{d}$ & $\mathrm{b} / \mathrm{d}$ & $\mathrm{b} / \mathrm{d}$ & $\mathrm{b} / \mathrm{d}$ \\
\hline SVK & $(0810)$ & 861,04 & 22,47 & 38,31 & 1385,70 & 22,47 & 61,67 \\
\hline SVN & (0820) & 16,9 & 1,69 & 10,00 & 324,80 & 1,69 & 192,19 \\
\hline
\end{tabular}

Źródło: opracowanie własne na podstawie danych FADN UE.

Aktywa trwałe (obejmują ziemię rolniczą, budynki gospodarstwa rolnego, nasadzenia leśne oraz maszyny i urządzenia, zwierzęta stada podstawowego oraz środki trwałe będące w fazie inwestycji) podzielone na liczbę zatrudnionych (nakłady pracy SE) dają wskaźnik kapitału przypadającego na jednego zatrudnionego. Najwyższą wartość zaobserwowano w regionie (0780) Malta (294,63 tys. EUR) i regionie (0820) Slovenia (192,19 tys. EUR), a najniższą w regionach (0834) Yugozapaden (15,11 tys. EUR), i (0835) Yuzhentsentralen (15,11 tys. EUR). Regiony polskie wykazują następującą wartość wskaźnika: Pomorze i Mazury (138,66 tys. EUR), Wielkopolska i Śląsk (147,02 tys. EUR), Mazowsze i Podlasie 
(112,81 tys. EUR), Małopolska i Pogórze (60,51 tys. EUR) w przeliczeniu na jednego zatrudnionego (tab. 6).

Środki trwałe ogółem (SE441) w odniesieniu do nakładów pracy ogółem (SE010), wskazują wartość aktywów trwałych przypadających na roczną jednostkę pracy (ekwiwalent osoby pełnoetatowej) tworząc porównywalny wskaźnik dla regionów FADN UE13.

\section{Podsumowanie i wnioski}

Analiza danych wykazała, że średnie nakłady pracy ogółem (SE010) oraz średnia powierzchnia użytków rolnych (SE025) w gospodarstwach rolnych specjalizujących się w chowie bydła mlecznego w regionie FADN Pomorze i Mazury oraz Wielkopolska i Śląsk były wyższe niż w Polsce, natomiast w regionie Mazowsze i Podlasie oraz Małopolska i Pogórze średnie niższe niż w Polsce.

W analizowanym okresie średnia wartość aktywów trwałych (SE441), w regionach FADN Pomorze i Mazury oraz Wielkopolska i Śląsk jest wyższa niż w Polsce. W regionie FADN Mazowsze i Podlasie wartość aktywów trwałych jest równa średniej w Polsce, a w regionie FADN Małopolska i Pogórze jest niższa od średniej krajowej.

Wzrost wartości aktywów trwałych w gospodarstwach rolnych specjalizujących się w chowie bydła mlecznego w Polsce jest spowodowany głównie wysokim udziałem ziemi. W 2006 roku w Polsce był on na poziomie 19,13\%, a w 2017 roku udział ten wyniósł już $51,69 \%$. Powierzchnia użytków rolnych w 2017 roku wzrosła nieznacznie w stosunku do 2006 roku bo tylko o 2,49 ha. Podobna sytuacja jest w regionie Wielkopolska i Śląsk, w którym w 2006 roku udział ziemi rolniczej w wartości aktywów trwałych wynosił 21,13\%, a w 2017 roku już 54,53\%. Natomiast powierzchnia użytków rolnych w 2017 roku w stosunku do 2006 roku zwiększyła się tylko o 0,82 ha. Dla porównania, w Bułgarii nie nastapił wzrost udziału ziemi rolniczej $\mathrm{w}$ wartości aktywów trwałych. W roku początkowym badanego okresu w Bułgarii ziemia rolnicza miała udział w wartości aktywów trwałych na poziomie $19,68 \%$, a $\mathrm{w}$ roku końcowym $15,29 \%$, natomiast odnotowano znaczący wzrost powierzchni użytków rolnych jednego gospodarstwa mlecznego z 6,61 ha na 16,92 ha. W regionach (0833) Severoiztochen i (0836) Yugoiztochen nastapił znaczący wzrost wartości aktywów trwałych, spowodowany zwiększeniem powierzchni UR. W regionie FADN UE (0833) Severoiztochen w roku początkowym badanego okresu udział ziemi rolniczej w wartości aktywów trwałych stanowił $36,02 \%$, a w końcowym $11,11 \%$. Natomiast powierzchnia użytków rolnych początkowo była na poziomie 3,72 ha, a w 2017 roku wynosiła już 17,04 ha. Podobnie było $\mathrm{w}$ regionie (0836) Yugoiztochen $\mathrm{w}$ roku początkowym badanego okresu udział ziemi rolniczej w wartości aktywów trwałych stanowił $22,59 \%$, a w końcowym $11,35 \%$. Z kolei powierzchnia użytków rolnych początkowo wynosiła 6,97 ha, a w 2017 roku 32,84 ha.

Gospodarstwa mleczne w regionach FADN w Polsce w porównaniu do regionów FADN UE13 mają wyższy od średniej wartość majtku trwałego przypadającego na jednego zatrudnionego. Nastapiło to nie tylko dzięki wzrostowi cen ziemi, ale także dzięki inwestycjom wpieranym przez WPR.

Reasumując można stwierdzić, że w latach 2006-2017 zróżnicowanie czynników produkcji $\mathrm{w}$ gospodarstwach rolnych specjalizujących się $\mathrm{w}$ chowie bydła mlecznego zależało głównie od uwarunkowań regionalnych. Generalnie kraje UE13 wykazują słabsze wyposażenie w majątek trwały i charakteryzują się gorszą sytuacją ekonomiczną w porównaniu do bardziej rozwiniętych krajów UE15. 


\section{Literatura}

Bórawski, P. (2013). Czynniki różnicujące efektywność gospodarstw rolnych uzyskujących dochody z działalności alternatywnych i komplementarnych (Factors differentiating effectiveness of farms receiving income from alternative and complementary activities). Rozprawy i monografie 185 . Wydawnictwo UWM w Olsztynie.

Czaja, S., Becla, A. (2007). Ekologiczne podstawy procesów gospodarowania (Ecological basis of management processes). Wyd. Akademii Ekonomicznej im. Oskara Langego we Wrocławiu, Wrocław.

Czyżewski, A., Kryszak, Ł. (2015). Sytuacja dochodowa gospodarstw rolniczych w krajach UE-15 i w Polsce w latach 2007-2013 w świetle statystyki FADN (Income situation of agricultural holdings in EU-15 member states and Poland in the years 2007-2013 in the light of the FADN statistics). Problemy Rolnictwa Światowego, 15(1), 21-32.

EU dairy farms report based on 2016 FADN data, 2018. European Union.

Floriańczyk, Z., Osuch, D., Płonka, R. (2017). Polski FADN. Wyniki standardowe uzyskane przez gospodarstwa rolne uczestniczące w polskim FADN w 2016 roku (Polish FADN. Standard results obtained by farms. farms participating in the Polish FADN in 2016). Warszawa: IERiGŻ-PIB.

Gołębiewska, B. (2010). Kierunki podejmowanych działań inwestycyjnych w gospodarstwach rolnych o zróżnicowanych powiązaniach $\mathrm{z}$ otoczeniem (The directions of investment in the farms depend on the strength of their markets relations). Roczniki Nauk Rolniczych. Seria G 97 (4), 6-68.

Grzelak, A. (2015). Determinanty zasobowe procesów reproducji majatku gospodarstw rolnych prowadzących rachunkowość rolną (FADN) (Resource determinants of reproduction rpocesses of assets of farms engaged In agricultural accountancy (FADN). Roczniki Naukowe SERiA 17(2), 69-74.

GUS (CSO). 2018. Rocznik statystyczny rolnictwa (Statistical Yearbook of agriculture). Warszawa: GUS.

Kołodziejczak, M., (2014). Efektywność wykorzystania czynników produkcji w rolnictwie polskim i niemieckim w latach 2004-2012 (Efficiency of Production Factors in Agriculture of Poland and Germany in 2004-2012). Roczniki Naukowe Ekonomii Rolnictwa i Rozwoju Obszarów Wiejskich, 101(2), 70-79.

Parzonko A. (2013). Regionalne zróżnicowanie produkcji mleka w Polsce-uwarunkowania przyrodnicze i ekonomiczne (Regional differences in milk production-natural and economic determinants). Roczniki Naukowe SERiA 15(2), 265-270.

Sass, R. (2009). Wpływ wielkości stada i mleczności krów na koszty produkcji mleka w gospodarstwach utrzymujących bydło mleczne (Influence of the size of the herd of cows on the production costs at farms keeping dairy cattle). Rocz. Ekon. KPSW 2, 218-230.

Sass, R. (2015). Efektywność ekonomiczna gospodarstw rolniczych w zależności od zmian powierzchni użytków rolnych - ocena w latach 1996-2011 (Economic efficiency of farms depending on area of agricultural land changes - assessment in the years 1996-2011). Roczniki Naukowe SERiA 17(5), 238-245.

Skarżyńska, A. 2011: Skala produkcji rolniczych działalności produkcyjnych a ich opłacalność (The scale of agricultural production activities and their profitability). Roczniki Nauk Rolniczych. Seria G, 98(1), 10-19.

Wysokiński, M., Klepacki, B. (2013). Poziom i parytet dochodów gospodarstw mlecznych o różnym stopniu koncentracji produkcji (The level and parity of dairy farms incomes in dependence on different scale of production). Zagadnienia Ekonomiki Rolnej, 4, 63-70.

Ziętara, W. (2012). Organizacja i ekonomika produkcji mleka w Polsce, dotychczasowe tendencje i kierunki zmian (Organisation and the economics of milk production in Poland, trends and the past and future). Roczniki Nauk Rolniczych. Seria G, 99(1), 43-57.

Do cytowania / For citation:

Bórawski P., Kalinowska B., Kochanowicz Z. (2019). Zróżnicowanie czynników produkcji w gospodarstwach rolnych specjalizujących się w chowie bydła mlecznego w regionach FADN w Polsce w latach 2006-2017 na tle UE13. Problemy Rolnictwa Światowego, 19(3), 5-15; DOI: 10.22630/PRS.2019.19.3.41

Bórawski P., Kalinowska B., Kochanowicz Z. (2019). Differentiation of Production Factors in Agricultural Farms Specializing in Dairy Cattle in FADN Regions in Poland in the Years 20062017 vis-à-vis the EU13 (in Polish). Problems of World Agriculture, 19(3), 5-15; DOI: 10.22630/PRS.2019.19.3.41 